\title{
Characteristics of physical activity among pregnant women
}

\author{
Andreja Rijavec', David Ravnik², Mirko Prosen² \\ I Community Health Centre Nova Gorica, Rejčeva ulica 4, 5000 Nova Gorica, Slovenia \\ ${ }^{2}$ University of Primorska, Faculty of Health Sciences, Department of Nursing, \\ Polje 42, 6310 Izola, Slovenia \\ andreja.rijavec@gmail.com
}

\begin{abstract}
Introduction: Moderate physical activity should be a part of every day life during pregnancy of course if the woman does not have any health problems or any complications relating to pregnancy. The aim of the research was to determine how and in which way pregnant women are physical active and if there is any correlation between physical activities during pregnancyregardless of their socio-demographic characteristics. Methods: The nonexperimental empirical method was used. Semistructured questionnaire was applied on convenience sample of pregnant women $(n=46)$ who had been attending prenatal education courses in December 2015 and January 2016. The average age of the respondents was 29 years $(s=4.0)$. The majority of them $(39.9 \%)$ had completed an upper secondary education; lived in rural areas (63\%); were in 29 th week of gestation $(s=6)$ and were primiparous (84.8\%). In addition to the basic descriptive statistics Pearson correlation coefficient was used. Results: The results suggest that pregnant women are trying to be physical active during pregnancy, because they are aware of its positive effects on pregnancy, childbirth and know the reasons when physical activity is contraindicated. The majority of them are engaged inphysical activity four times per week; walking is the most common type (54.5\%); only $19.6 \%$ of pregnant women attend organized physical exercises for pregnant women. Multiparous women compared with primiparous women are more physically active $(\mathrm{p}=0.543)$. Age, levelof education and place of residence are not statistically significantly associated with the implementation of physical activity in everyday life ( $\mathrm{p}>0.05)$. Discussion and conclusions: One of the most important factors that contribute to a healthy pregnancy, childbirth and postpartum period is physical activity during pregnancy. The results suggest that pregnant women are well aware of these effects, but the implementation of physical activity
\end{abstract}


is not always proportional to this. Organized physical exercises, where established, are insufficient for adequate preparation for childbirth.

Key words: physical activity, pregnancy, health, lifestyle, fetus

$\mathrm{R}$

egular, appropriate and adapted to the appropriate intensity physical activity is nowadays one of the most important factors of a healthy lifestyle and has an extremely positive effect on the human organism (Videmšek et al., 2015). In addition Videmšek at al. (2015) report that moderate physical activity during pregnancy should also be a part of an expectant mothers' everyday life; if the latter does not have any health problems or any complications relating to the pregnancy.

Physical activity during pregnancy, initially has a very positive impact on the health of pregnant women and the developing fetus, but it has also proved to be extremely helpful in preparation for childbirth (Videmšek et al., 2015). Blenkuš et al. (2015) claim that various research shows that physical activity during pregnancy reduces the occurrence of certain risk factors, thereby reducing the risk of poor health of pregnant women and the fetus. Physical activity has a beneficial effect on both the immune system and the mental state of pregnant women.

In the case of a pregnant, healthy woman, there is almost no reason to avoid physical activity. If the pregnant woman is both physically and mentally well prepared the birth will be easier and recovery faster. A suitable physical activity in combination with a healthy diet has a positive effect on fetal growth and development, contributing to better health and to facilitate childbirth and a faster return to physical fitness after childbirth itself (Mlakar et al., 2011).

The aim of the research was to determine how much and how physically active womenare during pregnancy, and what connection there is between physical activity during pregnancy, and their socio-demographic characteristics.

\section{Methods \\ Sample description}

The sample included 46 women.They attended schools for future parents in the period from mid-December 2015 till the end of January 2016. The average age of the respondents was 29 years $(s=4.0)$. From the sample $39.9 \%$ had completed secondary education; live in rural areas: $63 \%$; on average, they were 29 weeks intothe pregnancy $(s=6)$ and primiparous women: $84.8 \%$.

\section{Description of the instrument}

The method of data collection based on a questionnaire consisted of 20 questions mostly closed type. The questions are divided into three sections. The first part of the questionnaire includes demographic information, a second set cov- 
ers issues relating to the implementation of physical activity during pregnancy,the appropriate choice of activities during pregnancy and knowledge of the positive effects of physical activity during pregnancy and it impact on pregnancy and childbirth.In the third part, the respondents were offered the opportunity to express their opinions and feelings.

\section{Data processing}

The survey was conducted between 15/12/2015 and 31/1/2016. Participation was voluntary and anonymous. Participants were presented the aims and objectives of the study and given the option of feedback.

The data were analysed after the completion of the program using an excel spreadhseet. It was decided that the best way to test the hypotheses was to use Pearson's correlation coefficient. The statistical significance level of $p<0.05$ was applied.

\section{Results}

Our results showed that more than half (69.6\%) of women surveyed were already physically active before pregnancy. Before pregnancy, women prefered walking (brisk walking, hiking). This form of activity is carried out by almost a third (28.1\%) of respondents. This was followed by other types of physical activity, such as jogging, fitness, cycling and aerobics. All these activities, most respondents $(77.4 \%)$ before pregnancy carried out several times a week, while other respondents (13\%) were physically active only once a week. Some women surveyed were active every day (9.7\%).

Physical activity was discouraged in 8 pregnant women (17.4\%). 33 pregnant women $(71.7 \%)$ confirmed that they were regularly physically active during pregnancy. The type and level of physical activity during pregnancy slightly changed. Still, more than half $(54.5 \%)$ of the respondents decided to walk. Almost $20 \%(19.6 \%)$ of women attended an organised exercise for pregnant women, less than $15 \%$ of the women conducted yoga and aerobics, ran and swam. On average they exercise regularly 4 times a week. Runtime exercise is varied from a minimum of 14 minutes to 120 minutes, on average, 48 minutes. The proportion of women who were active once a week before pregnancy, decreased their physical activity during pregnancy, in comparison with proportion of those who were active before pregnancy every day, but during pregnancy they increased their physical activity.

According to the other results of the study we canadopted certain conclusions such as:

- $\quad$ demographic factors such as age $(\mathrm{p}=0.06)$, education level $(\mathrm{p}=$ o.28) and living environment $(\mathrm{p}=0.08)$ can not affect the physical activity of women; 
- $\quad 71,7 \%$ of those women, who parcitipated in the survey and who are physically active during pregnancy, believe that the doing physical activity during pregnancy does not endanger the health of their fetus or cause it to be lost, just the opposite;

- $\quad 100 \%$ of women who participated in the survey, believe that physical activity during pregnancy could have a significantly positive impact on the health of the child and themselves, women were generally well aware of the positive effects of doing physical activity during pregnancy to childbirth and fetal development, and the belief that activity during pregnancy harms the health of the fetus is no longer valid;

- those women who have already had experiences with pregnancy and childbirth, find it easier to opt for physical activity during pregnancy and are more physically active $(\mathrm{p}=0.54)$.

\section{Discussion}

If the results of our research are compared with the results of the survey, which Makara-Studzinska et al. (2013) conducted in Poland, we see that the majority of women in the Polish study ( $71 \%$ of respondents) were physically active before pregnancy, the percentage of active of women during pregnancy also increased. Before pregnancy, in the Polish study (ibid.), women prefer walking. Other practiced aerobics, few werecyclists, attended gym, swimming and running. The Polish study also founds that the majority of women surveyed before pregnancy were active several times a week, some at least every day. During pregnancy, the degree of physical activity change, as the majority of women were physically active once a week, a few less times a week, but at least every day.

Among the types of physical activity the most popular was walking, some of the women surveyed had chosen exercise at home, swimming, exercise and yoga for pregnant women. Just as in our study, the Polish study of Makara-Studzinska et al. (2013) shows that the relationship between physical activity before and during pregnancy is very low or non-existent.

With results of both studies (our and above mentioned Polish study) we can see the assertion that women,when they are recognising that they are pregnant, stop with physical activities and spend the rest of the pregnancy sitting down because of the convictionthat physical activity during pregnancy causes injury and the loss of a child, it is not valid anymore.

If, however, our research compared with the research of Merkxet al. (2017) conducted in the Netherlands, we see that more than half of the 455 healthy pregnant women participating in the survey of Merkx et al., decreased level of physical activity during pregnancy. Less than $5 \%$ of the women participating in the study of Merkx et al. (2017), increased physical activity during pregnancy. Which means that the results of that research, is in contrast with the results of our research. The results of our study showed that the proportion of wom- 
en surveyed who have opted for physical activity during pregnancy increased above the proportion of women surveyed who were physically active before pregnancy.

It is understood how important it is that pregnant women are properly informed about what is recommended during pregnancy. In conjunction with this, our research found that a $100 \%$ of women surveyed are aware of the positive effects of physical activity during pregnancy on pregnancy, childbirth, and on pregnant woman.

\section{Conclusions}

During pregnancy women's emotions are more intense, there is a psychological change, and the body makes both visible and invisible changes. Pregnancy is a happy and miraculous event and a lot of things start to change during this period. When women find out about being pregnant they frequently asked themselfs what they can do while pregnancy. One of the most important factors affecting the good course of the pregnancy, childbirth and the health of pregnant women and children, is definitely a physical activity of pregnant women. Just a while ago, on the news that they were pregnant, women stopped using all physical activity because they were convinced that physical activity would harm the development of their child and due to pregnancy they were among the most vulnerable groups of women. Since this the world and the way of life are constantly changing and new discoveries emerged, this belief has been somehow eradicated in women's perception. The results of our research showed that women today are well aware of the effects of physical activity during pregnancy on the health of the pregnant woman and the baby, and on pregnancy and child birth as well. They know when physical activity is advised during pregnancy and when should it be stopped. However, a lot more women choose physical activity during pregnancy precisely with the reason that they will contribute to the best possible development of the child, to the health of their own and to the easier and more beautiful course of pregnancy and childbirth.

\section{References}

BLENKUŠ, Š., ČEMAŽAR, V., VIDEMŠEK, M., HADŽIĆ, V., PIRKMAJER, S. and ROTOVNIK-KOZJEK, N., 2015. Pomen telesne dejavnosti v nosečnosti. In: NOVAK-ANTOLIČ, Ž., KOGOVŠEK, K., ROTOVNIK-KOZJEK, N. in MLAKAR-MASTNAK, D., ed. Klinična prehrana v nosečnosti. Ljubljana: Center za razvoj poučevanja, Medicinska fakulteta, Univerza v Ljubljani, pp. 145-160.

MAKARA-STUDZINSKA, M., KRYS-NOSZCZYK, K., STARCZYNSKA, M., SIERON, A. and SLIWINSKI, Z., 2013. Types of physical activity during pregnancy [online]. Polish annals of medicine, 2013, no. 20, pp. 19-24. [Viewed 19.1.2015]. Available from: http://www.sciencedirect.com/science/article/pii/S1230801313000052 
MERKX, A., AUSEMS, M., BUDE, L., DE VRIES, R. and J. NIEUWENHUIJZE, M., 2017. Factors affecting perceived change in physical activity in pregnancy [online]. Midwifery, 2017, vol. 51, no. 9, pp. 16-32. [Viewed 5. 6. 2017]. Available from: http://www.midwiferyjournal.com/article/So2666138(17)30352-2/fulltext

MLAKAR, K., VIDEMŠEK, M., VRTAČNIK-BOKAL, E., ŽGUR, L. and ŠĆEPANOVIĆ, D., 2011. Z gibanjem v zdravo nosečnost. Ljubljana: Univerza v Ljubljani, Fakulteta za šport, pp. 7.

VIDEMŠEK, M., BOKAL-VRTAČNIK, E., ŠĆEPANOVIĆ, D., ŽGUR, L., VIDEMŠEK, N., MEŠKO, M., KARPLJUK, D., ŠTIHEC, J. and HADŽIĆ, V., 2015. Priporočila za telesno dejavnost nosečnic. Zdravniški vestnik, vol. 84 , no. 2 , pp. 87-98. 